\title{
PROGRAM PENINGKATAN KUALITAS DAN EFEKTIVITAS PROSES BELAJAR DARING DI TENGAH PANDEMI VIRUS CORONA
}

\author{
Nurdinni Tilova, Muhamad Guruh, Hendri Gunawan, Devi Putri Isnaeni, \\ Henni Marlinah \\ dosen02216@unpam.ac.id
}

\begin{abstract}
The purpose of carrying out community service activities is to provide counseling and questions and answers on the importance of improving the quality and effectiveness of the online learning process during the coronavirus pandemic so that the online learning process can be carried out well, and students easily understand the material presented by educators. This method of community service activities takes place from November to December 2020 and consists of three stages of activity. The first stage is the preparation stage in surveying partner locations, activity participants, and preparing materials. The second stage is the implementation which includes giving lectures on Improving the Quality and Effectiveness of Online Learning Processes in the Middle of the Corona Virus Pandemic. The third stage is evaluation, among others, to find out how deep the training participants understand the material given. This community service activity concludes that Muhammadiyah Parakan Vocational School only uses the WhatsApp application in conducting online learning, so distance learning activities are less effective. There need to be other applications that this school uses so that teachers can deliver the material effectively, and students can understand the material presented.
\end{abstract}

Keywords: Quality, Effectiveness, Online Learning Process

\begin{abstract}
ABSTRAK
Tujuan dilaksanakannya kegiatan pengabdian masyarakat adalah untuk memberikan penyuluhan serta tanya jawab akan arti pentingnya meningkatkan kualitas dan efektivitas proses belajar daring di tengah pandemi virus corona, agar proses pembelajaran daring dapat terlaksana dengan baik, dan siswa dengan mudah memahami materi yang disampaikan para pedidik. Metode kegiatan pengabdian kepada masyarakat ini berlangsung dari bulan November sampai dengan Desember 2020 dan terdiri dari tiga tahapan kegiatan. Tahapan pertama yaitu tahap persiapan dalam melakukan survey lokasi mitra, peserta kegiatan dan penyusunan materi. Tahap ke dua yaitu pelaksanaan yang meliputi pemberian ceramah materi Peningkatan Kualitas dan Efektivitas Proses Belajar Daring di Tengah Pandemi Virus Corona. Tahap ketiga yaitu evaluasi antara lain untuk mengetahui seberapa dalam pemahaman peserta pelatihan terhadap materi yang diberikan. Kesimpulan dari kegiatan pengabdian masyarakat ini adalah SMK Muhammadiyah Parakan hanya menggunakan aplikasi whatsapp dalam melakukan pembelajaran daring, sehingga kurang efektifnya kegiatan belajar jarak jauh. Perlu adanya aplikasi lain yang
\end{abstract}


digunakan sekolah ini agar guru dapat menyampaikan materinya dengan efektif, serta siswa dapat memahami materi yang disampaikan.

Kata Kunci : Kualitas, Efektivitas, Proses Belajar Daring

\section{A. PENDAhULUAN}

Saat ini berbagai negara di belahan dunia, tengah dilanda dengan wabah suatu penyakit yang disebabkan oleh virus bernama corona atau lebih dikenal dengan istilah covid-19 (Corona Virus Diseases-19). Virus ini awalnya mulai berkembang di Wuhan, China. Wabah virus ini memang penularannya sangat cepat menyebar ke berbagai negara di dunia. Sehingga oleh World Health Organization (WHO), menyatakan wabah penyebaran virus covid-19 sebagai pandemi dunia saat ini.

Akibat dari pandemi covid-19 ini, menyebabkan diterapkannya berbagai kebijakan untuk memutus mata rantai penyebaran virus covid-19 di Indonesia. Upaya yang dilakukan oleh pemerintah di Indonesia salah satunya dengan menerapkan himbauan kepada masyarakat agar melakukan physical distancing yaitu himbauan untuk menjaga jarak diantara masyarakat, menjauhi aktivitas dalam segala bentuk kerumunan, perkumpulan, dan menghindari adanya pertemuan yang melibatkan banyak orang. Upaya tersebut ditujukan kepada masyarakat agar dapat dilakukan untuk memutus rantai penyebaran pandemi covid-19 yang terjadi saat ini. Pemerintah menerapkan kebijakan yaitu Work From Home (WFH). Kebijakan ini merupakan upaya yang diterapkan kepada masyarakat agar dapat menyelesaikan segala pekerjaan di rumah. Pendidikan di Indonesia pun menjadi salah satu bidang yang terdampak akibat adanya pandemi covid-19 tersebut.

Sistem pembelajaran online adalah mutlak diperlukan untuk mengantisipasi perkembangan jaman dengan dukungan teknologi Informasi di mana semua menuju ke era digital (era revolusi industri 4.0), baik mekanisme maupun konten yang digunakan (Aidah, 2019). Seiring dengan perkembangan teknologi yang kian pesat, pembelajaran daring juga merupakan salah satu cara untuk meningkatkan kualitas pendidikan memasuki era revolusi industri 4.0. Oleh karena itu pada pembahasan akan dijabarkan mengenai pembelajaran secara daring yang meliputi definisi, kategori, komponen pendukung, platform pembelajaran daring gratis dari pemerintah, manfaat, tantangan, serta metode yang dapat digunakan dalam pembelajaran daring. Penjabaran tersebut bertujuan untuk memberikan pandangan baru tentang pembelajaran daring di masa pandemi di mana nantinya para pelaku pendidikan diharapkan dapat mengambil langkah terbaik dalam pelaksanaannya.

Sekolah Menengah Kejuruan merupakan lembaga formal yang diharapkan dapat melahirkan tenaga kerja kompeten yang siap menghadapi industri kerja yang kian berkembang seiring dengan kemajuan teknologi. Keahlian kerja, kemampuan beradaptasi dan pola pikir yang dinamis menjadi tantangan bagi sumber daya manusia, di mana selayaknya dapat diperoleh saat mengenyam pendidikan formal di Sekolah Menengah Kejuruan. Untuk memperlancar pelaksanaan pembelajaran daring selama pandemi Covid-19 di SMK perlu didukung oleh beberapa komponen, data diambil berdasarkan kajian pustaka dan pengalaman dari pengajar. Infrastruktur, Sistem aplikasi, Konten, Operator.

Tantangan Pembelajaran Daring Pembelajaran daring memberikan banyak manfaat untuk proses pembelajaran, tetapi selain manfaat ada beberapa tantangan yang dihadapi baik oleh pengajar dan pembelajar dari pemberlakuan pembelajaran daring selama masa pandemi serta dari kajian pustaka.

Kurangnya interaksi dalam pembelajaran. Interaksi antara pengajar dan pembelajar diperlukan dalam pembelajaran sehingga pengajar dapat menilai kemampuan kognitif, afektif 
dan psikomotorik pembelajar secara utuh. Dalam pembelajaran daring banyak faktor yang menyebabkan kurangnya interaksi pembelajaran salah satunya adalah sinyal internet yang kurang baik dapat memperlambat reaksi pengajar dalam merespons pertanyaan pembelajar begitu pun sebaliknya.

Untuk membatu dalam masalah ini maka kami akan mensosialisasikan dan memberikan penyuluhan kepada siswa SMK Muhammadiyah Parakan, dengan tema "Program Peningkatan Kualitas Dan Efektivitas Proses Belajar Daring Di Tengah Pandemi Virus Corona”.

\section{B. METODE PELAKSANAAN KEGIATAN}

Metode kegiatan yang dilakukan kepada siswa sekolah SMK Muhammadiyah Parakan adalah berupa pelatihan langsung dengan tatap muka di kelas melibatkan siswa kelas 10 , kelas 11 dan guru di sekolah tersebut, selanjutnya forum diskusi interaktif dengan siswa di kelas, dengan adanya forum diskusi ini memberikan fasilitas kepada siswa untuk mengajukan pertanyaan-pertanyaan terkait pembelajaran daring di tengah pandemic virus corona.

Program Pengabdian kepada Masyarakat di sekolah SMK Muhammadiyah Parakan dibagi menjadi 3 tahap yaitu, tahap pertama persiapan, melakukan survei lapangan, tahap kedua pelaksanaan yaitu pemberian materi dan pelatihan, dan tahap ketiga evaluasi. Berikut adalah alur dari setiap rangkaian kegiatan:

1. Tahap Persiapan

Adapun tahap-tahap yang dilakukan dalam Pengabdian kepada Masyarakat meliputi: Survei awal, pada tahap ini dilakukan ke lokasi sekolah SMK Muhammadiyah Parakan, Pamulang, Kota Tangerang Selatan. Setelah survei maka ditetapkannya waktu pelaksanaan dan sasaran peserta kegiatan. Penyusunan bahan/materi pelatihan

2. Tahap Pelaksanaan

Permasalahan yang ada bahwa siswa siswi SMK Muhammadiyah Parakan ini masih belum maksimal dalam pembelajaran daring. Waktu pelaksanaan program Pengabdian kepada Masyarakat ini berjalan pada hari Sabtu tanggal 21 November 2020. Program PKM ini dilaksanakan di sekolah SMK Muhammadiyah Parakan, Pamulang, Kota Tangerang Selatan.

3. Tahap Evaluasi

Pada tahap evaluasi ini untuk mengetahui seberapa dalam pemahaman peserta pelatihan terhadap materi yang diberikan dilakukan pendampingan, sosialisasi dan pelatihan secara langsung kepada peserta kegiatan secara bersama dengan mendatangi secara langsung sekolah SMK Muhammadiyah Parakan. Proses diskusi saat proses pelatihan ini sangat penting sebagai bahan evaluasi apakah PKM yang telah kita lakukan sudah berhasil atau belum. Tahap evaluasi ini dilaksanakan selama proses pelatihan berlangsung. Dalam tahap ini dilakukan sesi diskusi dan tanya jawab terhadap keaktifan dan kepuasan peserta.

\section{HASIL DAN PEMBAHASAN}

Kegiatan pengabdian kepada masyarakat Universitas Pamulang yang dilakukan dosen-dosen dan mahasiswa program studi Manajemen telah berjalan dengan lancar dan disambut dengan baik oleh guru dan siswa SMK Muhammadiyah Parakan. Pembelajaran daring di SMK Muhammadiyah Parakan dirasa kurang efektif, dikarenakan proses belajar daring hanya menggunakan aplikasi whatsapp, sehingga para siswa tidak terlalu banyak memahami materi yang diberikan oleh pendidik. 

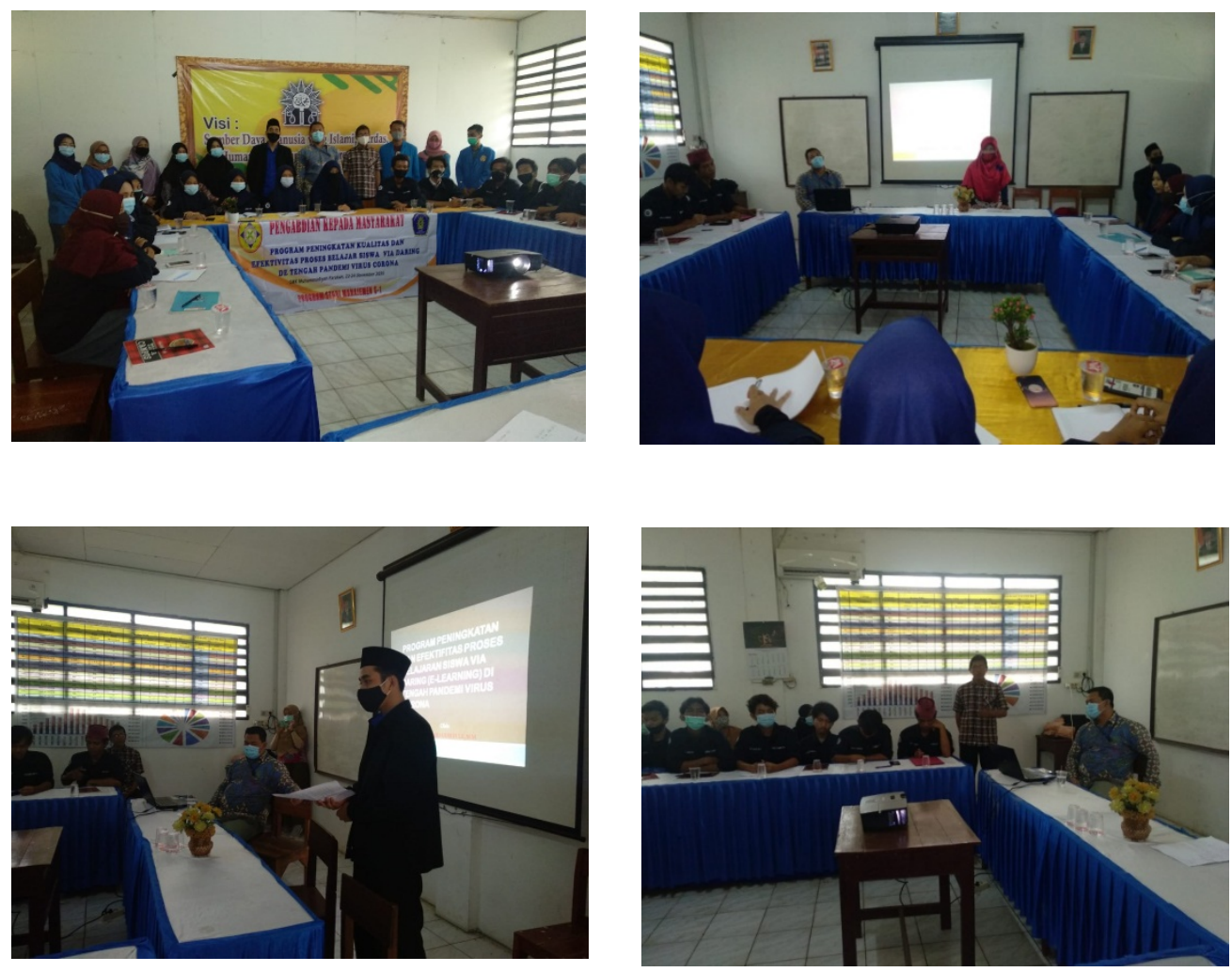

\section{Gambar 1. Photo Kegiatan PKM}

Siswa merasakan bahwa pengaplikasian pembelajaran daring yang mereka peroleh hanya berpusat pada pemberian tugas, rasio pemberian materi sangatlah kecil. Selain itu akses bertanya juga tidak seluas pada saat pembelajaran face to face, baik bertanya terhadap guru maupun teman. Maka dari itu pembelajaran face to face dirasa lebih efektif. Banyak pendidik dan peserta didik mengalami ketidak nyamanan dalam proses pembelajaran daring dengan berbagai sebab, seperti; ketiadaan sarana dan prasarana, ketidakmampuan mengoperasikan perangkat maupun situasi geografis daerah. Aplikasi yang dapat digunakan oleh pendidik dan siswa SMK Muhammadiyah Parakan tidak hanya whatsapp namun dapat menggunakan salah satu aplikasi yang cukup mudah dipergunakan adalah google classroom. Dengan berbagai keterbatasan, google classroom dapat menjadi jawaban atas kebutuhan sarana dalam pelaksanaan pelaksanaan pembelajaran yang tidak memungkinkan untuk tatap muka, dan dengan menggunakan aplikasi google classroom memudahkan siswa agar dapat memahami materi yang dipelajarinya.

Perancangan penggunaan google classroom yang baik akan memenuhi kebutuhan para peserta didik untuk mendapatkan proses yang lebih menarik, memahami dan berlatih serta berinteraksi dengan materi yang disajikan. Sehingga materi yang semula kaku dan hanya tulisan diam mampu diinteraksi menjadi lebih menarik sebagi output dalam belajar yakni memperoleh ilmu. Menurut Hidayat \& Sudibyo (2018) google classroom memiliki beberapa Keunggulanantara lani dlam dministrasi penilaian, kecepatan proses, paperless dan banyak kemudahan lainnya yang menyebabkan banyak penyelenggara pendidikan menggunakan layanan pendidikan tersebut. Fungsi yang ditawarkan bagi tenaga pengajar layaknya kelas konvensional dari proses mengajar (post), memberikan pertanyaan (create question), memberikan tugas (create assignment), serta membuat pengumuman (make announcement) 
tidak terbatas itu saja. Bahkan google classrom juga menyediakan layanan multimedia (video streaming) sebagai contoh dalam membantu pemahaman peserta didik. Pemanfaatan google classroom dapat melalui multiplatform yakni melalui komputer dan telepon genggam. Guru dan siswa dapat mengunjungi situs https://classroom.google.com atau mengunduh aplikasi melalui playstore di android atau app store di iOS dengan kata kunci google classroom. Penggunaan LMS tersebut tanpa dipungut biaya, sehingga pemanfaatannya dapat dilakukan sesuai kebutuhan (Wicaksono, \& Rachmadyanti, 2017).

Pembelajaran daring menjadi pilihan dalam berkomunikasi dan menyampaikan materi dan menerima tugas dari peserta didik. Dabbagh (2007) menyatakan bahwa ciri-ciri siswa dalam aktivitas belajar online atau daring yaitu, sebagai berikut:

1. Spirit Belajar

Siswa pada pembelajaran harus mempunyai semangat yang tinggi atau kuat guna pembelajaran mandiri. Pada pembelajaran daring siswa sendirilah yang menentukan kriteria ketuntasan belajar dan pemahaman materi. Siswa dibebankan untuk mandiri serta pengetahuan ditemukan sendiri. Kemandirian belajar mahasiswa menyebabkan perbedaan keberhasilan yang berbeda-beda.

2. Literacy terhadap Teknologi

Disamping kemandirian terhadap belajar, pemahaman siswa tentang pemakaian teknologi pada pembelajaran online merupakan keberhasilan dari pembelajaran daring. Penguasaan serta pemahaman tentang teknologi yang akan digunakan untuk pembelajaran daring merupakan hal yang harus dilakukan siswa sebelum pembelajaran online. Alat yang sering digunakan sebagai pembelajaran daring adalah laptop serta telpon pintar ataupun gadget lainnya. Dengan perkembangan era 4.0 semakin banyak vitur-vitur atau aplikasi yang digunakan sebagai sarana pembelajaran online.

3. Kemampuan Berkomunikasi Intrapersonal

Kemampuan interpersonal serta kemampuan berkomunikasi merupakan suatu hal yang harus dikuasai siswa agar berhasil dalam pembelajaran daring. Kemampuan interpersonal dibutuhkan untuk terjalinnya interakssi serta hubungan antar mahasiswa lainnya. Sebagai makhluk sosial tetap membutuhkan interaksi dengan orang lain meskipun pembelajaran online dilaksanakan secara mandiri. Oleh sebab itu tetap harus dilatih kemampuan interpersonal dan kemampuan komunikasi dalam kehidupan bermasyarakat.

4. Berkolaborasi

Memahami dan memakai pembelajaran interaksi dan kolaborasi. Pembelajaran daring dilaksanakan sendiri oleh siswa, oleh sebab itu siswa harus bisa berinteraksi dengan siswa lainnya ataupun dengan guru pada forum yang sudah disiapkan. Diperlukannnya interaksi tersebut terutama pada saat siswa mwngalami kesulitan memahami materi. Selain dari hal tersebut siswa perlu menjaga interaksi untuk melatih jiwa sosial mereka. Supaya tidak terbentuk menjadi seorang yang sangat individualisme dan anti social yang di karenakan pembelajaran daring. Dengan adanya pemmbelaaran daring juga siswa mampu memahami pembelajaran dengan kolaborasi. Siswa akan dilatih agar mampu berkolaborasi baik dengan lingkungan sekitar atau dengan bermacam sistem yang mendukung pembelajaran daring.

5. Keterampilan untuk Belajar Mandiri

Kemampuan akan belajar mandiri merupakan karakteristik dari pembelajaran daring. Dalam pembelajaran daring sangat diperlukan untuk terampil belajar secara mandiri. Karena pada saat proses belajar, siswa akan mencari, menemukan dan menyimpulkan yang telah dipelajari secara mandiri. Dalam situasi pembelajaran daring ini pendidik dapat 
memanfaatkan salah satu aplikasi dalam google yaitu google clasroom. Google classroom merupakan kelas maya yang dibentuk menyerupai kelas fisik.

Ada hal yang perlu diperhatikan saat siswa mengikuti pembelajaran daring, agar pembelajaran online atau daring bisa berjalan secara efektif dan berkualitas, sehingga dampak dari pandemi virus corona tidak terlalu berpengaruh terhadap dunia pendidikan. Beberapa cara agar pembelajaran daring menjadi efektif, yakni:

1. Siapkan fasilitas penunjang

Ini yang harus siapkan jika ingin pembelajaran daring: Kuota internet Aplikasi penunjang Laptop/komputer Materi pelajaran seperti buku, catatan, dan lainnya.

2. Jadwal harus disesuaikan

Jangan sampai sekolah atau kuliah diliburkan, terus dipakai untuk liburan. Tetapi siswa harus belajar dari rumah. Peran orangtua akan sangat penting terutama untuk siswa sekolah.

3. Kendalikan diri

Ketika belajar jarah jauh, tentu guru tidak ada di samping siswa. Maka siswa harus bisa mengendalikan diri dengan benar-benar belajar, bukan malah untuk main game, nonton tv atau main handphone terus.

4. Cari tempat yang nyaman Untuk belajar

Bisa pilih waktu yang tepat serta tempat yang nyaman. Sehingga siswa bisa mengerjakan dengan baik.

\section{KESIMPULAN DAN SARAN}

\section{Kesimpulan}

SMK Muhammadiyah Parakan hanya menggunakan aplikasi whatsapp dalam melakukan pembelajaran daring, sehingga kurang efektifnya kegiatan belajar jarak jauh. Perlu adanya aplikasi lain yang digunakan sekolah ini agar guru dapat menyampaikan materinya dengan efektif, serta siswa dapat memahami materi yang disampaikan.

Keberhasilan guru dalam melakukan pembelajaran daring pada situasi pandemi virus corona ini adalah kemampuan guru dalam berinovasi merancang, dan meramu materi, metode pembelajaran, dan aplikasi apa yang sesuai dengan materi dan metode. Kreatifitas merupakan kunci sukses dari seorang guru untuk dapat memotivasi siswanya tetap semangat dalam belajar secara daring (online) dan tidak menjadi beban psikis.

Kesuksesan pembelajaran daring selama masa pandemi virus corona ini tergantung pada kedisiplinan semua pihak. Oleh karena itu, pihak sekolah perlu membuat skema dengan menyusun manajemen yang baik dalam mengatur sistem pembelajaran daring. Hal ini dilakukan dengan membuat jadwal yang sistematis, terstruktur dan simpel untuk memudahkan komunikasi orangtua dengan sekolah agar putra-putrinya yang belajar di rumah dapat terpantau secara efektif.

\section{Saran}

Berdasarkan pengalaman dari pelaksanaan kegiatan ini maka dapat diajukan saran sebagai berikut:

1. Diharapkan guru maupun pihak sekolah dapat mengontrol dan membimbing siswanya dalam menggunakan aplikasi yang dipakai saat pembelajaran daring, agar dapat melaksanakan pembelajaran daring secara efektif.

2. Diharapkan kegiatan ini dapat dilaksanakan di berbagai sekolah untuk menginformasikan bagaimana cara meningkatkan kualitas dan efektivitas pembelajaran daring. 


\section{E. DAFTAR PUSTAKA}

Dabbagh, N. (2007). The online learner: Characteristics and pedagogical implications. Contemporary Issues in Technology and Teacher Education, 7(3), 217-226.

Dewi, W. A. F. (2020). Dampak COVID-19 terhadap Implementasi Pembelajaran Daring di Sekolah Dasar. EDUKATIF: JURNAL ILMU PENDIDIKAN, 2(1), 55-61.

Hasanah, A., Lestari, A. S., Rahman, A. Y., \& Daniel, Y. I. (2020). Analisis aktivitas belajar daring mahasiswa pada pandemi Covid-19. http://digilib.uinsgd.ac.id/30565/

Hidayat, W., \& Sudibyo, N. A. (2018). Implementasi Pembelajaran Interaktif Elektronika Dasar Menggunakan Adobe Flash Cs6 Pada Kelas Semu Dengan Google Classroom Berbasis Framework RAD. Jurnal Sains Dan Edukasi Sains, 1(2), 17-24.

Husamah. (2015). Pembelajaran Bauran (Blended Learning). Jakarta: Prestasi Pustaka

Lahinta, A. (2012). Berbagai Model Inovasi Pembelajaran dengan dukungan Teknologi Informasi. Prosiding APTEKINDO, 6(1), 9-16.

Noveandini, R., \& Wulandari, M. S. (2010). Pemanfaatan Media Pembelajaran Secara Online (E-learning) Bagi Wanita Karir Dalam Upaya Meningkatkan Efektivitas Dan Fleksibilitas Pemantauan Kegiatan Belajar Anak Siswa/i Sekolah Dasar. In Seminar Nasional Aplikasi Teknologi Informasi (SNATI).

Safrizal ZA, Putra, D. I., Sofyan, S. \& Bimo (2020). Pedoman Umum Menghadapi Pandemi Covid-19 Bagi Pemerintah Daerah. Pencegahan, Pengendalian, Diagnosis dan Manajemen.

Sagala, Syaiful. (2009). Konsep dan Makna Pembelajaran. Bandung: CV. 